\title{
A Study on Volatility Spillover of Stock Return and Gross Domestic Product with Reference to (BRCS) Countries
}

\author{
Effulgence \\ Vol. 17, No. 2 \\ July - December 2019 \\ Rukmini Devi Institute of Advanced Studies \\ E-mail : effulgence@rdias.ac.in, Website : www.rdias.ac.in \\ http://effulgence.rdias.ac.in/user/default.aspx \\ https://dx.doi.org/10.33601/effulgence.rdias/v17/i2/2019/14-24
}

\begin{abstract}
Dr. N. S. Pandey ${ }^{1} \triangle$
Ms. S. Sabamaithily²

Dr. Meenu Pandey
\end{abstract}

\begin{abstract}
This research paper examines the volatility spillover between Gross Domestic Product (GDP) on Stock Return (SR) with reference to (BRCS). The study has been considered for the period from 2012 to 2016. The study concluded and found an existence of co-integration between GDP and SR. Further the study has identified that there is a volatility of SR in BRCS for the study during the period from 2012 to 2016.
\end{abstract}

Keywords: Unit Root Test, Gross Domestic Product, Stock Return, Volatility Spillover.

JEL Classification Code:B20, B21, B22.

\section{INTRODUCTION}

B razil, Russia, China and South Africa (BRCS) are considered to be one of the budding economies in the world. Macroeconomic indicators such as interest rates, inflation, Index of Industrial Production, stock prices, gold prices and exchange rate etc. play a vital role in determining the growth as well as economic strength of any country in Global Arena. Stock market is a multi-dimensional concept. Macroeconomic factors are important when analyzing stock market development. Since stock markets are said to have played a role in promoting economic growth. Over the past few years, financial markets have been growing at global level. The integration of financial market across boundaries had been initiated by the capital market integration in developed countries. When the stock market is efficient then there will be a possibility of favorable impact of stock market on economic growth.

The word "BRICS" has been considered with five

1. Assistant Professor, Kanchi Mamunivar Centre for post Graduate Studies, Affiliated to Pondicherry Central University, drnspandey@gmail.com

2. Doctoral Research Scholar, Kanchi Mamunivar Centre for post Graduate Studies, Affiliated to Pondicherry Central University, maithilysaba@gmail.com

3. FCS and Company Secretary, Stellar Group of Companies, Noida India, meenuacs@gmail.com 
crucial emerging nations' economies i.e. "Brazil, Russia, India, China and South Africa". The assembly was primitively acknowledged as "BRIC" before the entry of South Africa in 2010. The first meeting was held in 2009 with member countries. In 2009 and 2010 two 'BRIC' summits were held proceeding to the enclosure of 'South Africa'. The first summit of five- "BRICS" member was held in 2011.

The following meetings were held in connection with "BRICS" :

\begin{tabular}{|c|c|c|}
\hline Summit & Date & Venue \\
\hline I & June 16, 2009 & 'Russia' Yakaterinburg. \\
\hline II & April 15, 2010 $B r a z i l '$ Brasilia. \\
\hline III & April 14, 2011 & 'China' Sanya. \\
\hline IV & March 29, 2012 India' New Delhi. \\
\hline V & March 26-27, 2013 & 'South Africa' Durban. \\
\hline VI & July 2014 Brazil' Fortaleza. \\
\hline VII & 2015 & 'Russia' Ufa. \\
\hline VIII & 2016 & 'India' Goa. \\
\hline IX & 2017 & 'China' \\
\hline X & July 2018 & 'South Africa' \\
\hline
\end{tabular}

Source: (BRICS Summit)1

\section{Literature Review}

The following past relevant studies are reviewed.

Jug and Marshall (1985) revealed the causal relationship between export and growth of 37 countries and it is found that export promotion policies just supported in 4 countries.

Reena et al. (1999)3, concluded in the study to determine the large changes in the volatility of emerging 'SM' returns and observe global local events (social, political and economic) during that periods of increased volatility. The findings of the study have positively significant in 'MEVs' in volatility
Rahman and Mustafa (1997) examined on the basis of selected 13 Asian developing countries for found co-integration between the real GDP and the real export for all countries. The findings show the direction which are mixed in short run and long run for the different countries. Amano and Van Norden (1998) the study found that oil prices were the main reason for US dollar exchange rate shocks. Nathan Taulbee (2000), the results of this study observed and suggested that both market and industries are influenced by the economic variables.

Wachtel (2000) and Beck and Levine Darat, Rahman and Zhong (2002) the study inferred that liquidity in stock market and in banking sector which can forecast the growth rate of economy. Raurava (2004) examined and concluded that there was rise in oil 
price which was concerned with decrease in Ruble during long period. Gurumurthy (2006) examined in the study that the financial sector have become strong in the market within the limitations framed by macroeconomic (ME) policy. Mohan (2007) Chakrabarti and De (2007) argued India was not much behind with China's economic growth since 19990s when economic liberalization process was started.

Ghosh (2011) examined the relationship between crude oil price (COP) and e (ER) in India during July, 2007 to November, 2008 and found that there was an increase in return on COP which showed the down fall in Indian rupee against the US \$. Olasunkanmi (2011), carried out AR-EGARCH technique was used to inspect the 'SMV' and 'MEVs' in Nigeria for the periods during 1986-2010 with the time series data. The findings of the study inferred that bi-casual relationship between 'SMV' and real GDP volatility in Nigeria was found. David (2012), observed on emerging market size and growth in "BRICS" countries. The study found that the "BRIC" countries-currently have the most emerging markets. Sagarika (2010), examined in the 'SM' in India is driven by macroeconomic fundamentals. The findings of the study of Least Square and semiparametric approaches, showed that semiparametric approach had better the SRs and volatility.

Cavalcanti and Jalles (2013) inferred a negative oil shocks which showed there was an appreciation in Brazilian currency. Rolland (2013), studied on the "BRICS" share of world trade, GDP, investment, and foreign currency reserve which are extensively expected to continue to grow and quickly to outface of OECD countries. "BRICS" nations are demanding more flexible terms in investment and trade agreements or have even refused outright to sign rigid agreements with the US. Bhagirath (2013), found in study and explored alternative role of the BRICS countries in global economic governance. A competent leadership was needed in the BRICS group in the domain of monetary, economic and trade. Rakesh (2013), the study inferred that industrial growth is a vital factor for influencing the stock market. The study was based on 12 Macroeconomic Variables (MEV) during 2001 to 2013. Anandan and Ramaswamy (2013) found that the relation is positively connected for crude oil prices and inflation growth rate during 2002-2011. The study found that oil and inflation are seen as being associated within a cause and effect framework.

Aparna (2013), examined the impact of crude oil prices (COP) on the Indian economy by comprising gross domestic product (GDP), index of industrial production (IIP) and WPI as the related variables. The study could not identify the relationship with the impact of COP on the variables used for the study as above. Vanita and Ritika (2014), investigated stock prices movement (SPM) which is not only based on behavior of important macroeconomic variables (MV) but SPM is a key factor of other MV in the economy.

Mohanamani and Sivagnanasithi (2014), the analysis of the study observed that Indian stock market is positively significant with WPI, money supply (MS) and industrial productivity (IP). The exchange rate (ER) and inflow of foreign institutional investment (FIIs) were showed insignificant with respect to Indian stock market. Jyoti and Mahakud (2015), the study concluded that macroeconomic volatility and equity market volatility were connected with each other. Gurloveleen and Bhatia (2015), the results of the study through Eviews are found to untangle the linkage between MV and stock market price. The study concluded that Indian stock market was too poor to be efficient during the period. Srinivasan (2016), the results showed that neither Export-led Growth nor Growth led have supported hypotheses in the short-run of Brazil and Russia. Shekhar and Debasish (2016), the study found positive and negative oil prices shock. The similar effects are found with respect to magnitude and exchange rate volatility. The result has shown a permanent effect on exchange rate volatility. Ghosh (2016), the results 
of the study showed a strong link among the variables (price, output, interest rate and money) by using structural vector auto regression.

The following objectives of the study are listed out:

- To assess long term relationship between stock return and Gross Domestic Product (GDP) from (BRCS)

- To examine the impact of stock return on GDP from (BRCS).

\section{Hypotheses Developed for the Study}

H01: Stock Return and Gross Domestic Product do not have long-run relationship in Brazil.

H02: Stock Return and Gross Domestic Product do not have long-run relationship in Russia

H03: Stock Return and Gross Domestic Product do not have long-run relationship in China

H04: Stock Return and Gross Domestic Product do not have long-run relationship in South Africa

H05: Stock Returns and Gross Domestic Product of Brazil are not co-integrated

H06: Stock Returns and Gross Domestic Product of Russia are not co-integrated

H07: Stock Returns and Gross Domestic Product of China are not co-integrated

H08: Stock Returns and Gross Domestic Product of South Africa are not co-integrated

H09: Causality does not exist between Stock Returns and Gross Domestic Product of Brazil

H010: Causality does not exist between Stock Returns and Gross Domestic Product of Russia

H010: Causality does not exist between Stock Returns and Gross Domestic Product of China

H010: Causality does not exist between Stock Returns and Gross Domestic Product of South Africa

\section{Research Design and Sources of Data}

The study is based on secondary data which are gathered from the Bloomberg and websites like www.bm\&fbovespa.com, www.micex.com, www.sse.com and www.jse.com. Theoretical framework of the data has been collected from various journals.

\section{Period of the Study}

The study has been considered during the year 201216 and data has been collected from a Bloomberg data base. The data consists of Quarterly basis of Gross Domestic Product and stock return. The study has covered the study period for 5 years quarterly data of calendar year i.e. from January 2012 to December 2016. Since the related data for the study period is not available in quarterly basis with respect to India. Therefore, India has not been included for the analysis. The data base has been concentrated as during the above mentioned period of the study.

\section{Statistical Tools Used :}

For analyzing the data, EVIEWS-9 has been used. The appropriate statistical techniques as Augmented Dickey-Fuller (ADF) Test, Phillips-Perron Test (Unit Root Test), Johanson Co-integration Test and Granger Causality Test have been used for analysis.

\section{Limitations of the Study :}

The study has the following limitations:

- It has comprised only the period for five years i.e. from January 2012 to December 2016 on quarterly data base.

- The study has taken only two major indicators as Gross Domestic Product and Stock Return. 
DATA ANALYSIS AND RESULTS:

Table 1: Unit Root Test

\begin{tabular}{|c|c|c|c|c|c|}
\hline \multirow{2}{*}{ Countries } & Indices & \multicolumn{2}{|c|}{$\begin{array}{c}\text { Augmented dickey-Fuller } \\
\text { Test }\end{array}$} & \multicolumn{2}{c|}{ Phillips Perron Test } \\
\cline { 2 - 6 } & & T-statistics & Probability & T-statistics & Probability \\
\hline \multirow{2}{*}{ Brazil } & $\begin{array}{c}\text { Gross Domestic } \\
\text { Product }\end{array}$ & -3.235172 & $0.0345^{* *}$ & -3.235172 & $0.0345^{* *}$ \\
\hline \multirow{2}{*}{ Russia } & Stock Return & -3.739426 & $0.0127^{* *}$ & -3.734852 & $0.0128^{* *}$ \\
\hline \multirow{2}{*}{ China } & Gross Domestic & & & & \\
& Product & -3.727412 & $0.0130^{* *}$ & -3.750110 & $0.0124^{* *}$ \\
\hline & Gross Domestic & -1.376326 & 0.5651 & -3.947572 & $0.0083^{*}$ \\
\hline \multirow{2}{*}{ South Africa } & Stoduct & -3.846415 & $0.0108^{* *}$ & -4.867662 & $0.0013^{*}$ \\
& Gross Domestic & -4.515073 & $0.0026^{*}$ & -4.512772 & $0.0026^{*}$ \\
& Product & -6.085392 & $0.0001^{*}$ & -10.04730 & $0.0000^{*}$ \\
\hline & Stock Return & -6.112432 & $0.0001^{*}$ & -6.093554 & $0.0001^{*}$ \\
\hline
\end{tabular}

Source: Compiled Data significant at 5\%**, 1\%*

Table 1 shows the following results:

The result of ADF test and Phillips Perron (PP) test are shown that $P$ value in 0.0345 and 0.0345 of GDP and respectively of Brazil. Hence, null hypothesis H01: "Stock Return and Gross Domestic Product do not have long-run relationship in Brazil", is significant at $5 \%$ level.

The $\mathrm{P}$ value of stock returns and GDP 0.0127 and 0.0128 respectively are significant at 5 per cent. The result of $\mathrm{ADF}$ and $\mathrm{PP}$ test of Russia shows that $\mathrm{P}$ value 0.0130 and 0.0124 respectively hence, the null hypothesis H02: "Stock Return and Gross Domestic Product do not have long-run relationship in Russia", is rejected at 5\%.

The $\mathrm{P}$ value ADF test of GDP and stock returns 0.0108 and 0.0026 respectively are shown significant at 5 and 1 per cent respectively. The result of PP test of China shows the $P$ value 0.0013 and 0.0026 respectively which is significant at 1 per cent, therefore, H03: "Stock Return and Gross Domestic Product do not have long-run relationship in China", is rejected at $1 \%$.

The P value ADF test of GDP and stock returns are 0.0001 and 0.0001 respectively. The result of PP test of South Africa shows that P value 0.0000 and 0.0001 respectively hence the null hypothesis H04: “Stock Return and Gross Domestic Product do not have long-run relationship in South Africa" is rejected at 1 per cent. The analysis of Unit Root Test showed for aforementioned hypotheses (H01, H02, H03, H04) are rejected at $1 \%$ and $5 \%$, Therefore, stock return and GDP of BRCS have long-run relationship. 
Table 2: Johansen Co-integration Test Unrestricted Co-integration Rank Test (Trace)

\begin{tabular}{|c|c|c|c|c|}
\hline $\begin{array}{l}\text { Hypothesized No. of } \\
\text { coefficients }\end{array}$ & Eigen Value & Trace Statistics & $\begin{array}{l}\text { 0.05 Critical } \\
\text { Value }\end{array}$ & Probability** $^{*}$ \\
\hline None * & 0.979212 & 218.1741 & 159.5297 & 0.0000 \\
\hline At most 1 * & 0.908944 & 144.5800 & 125.6154 & 0.0021 \\
\hline At most 2 * & 0.826206 & 99.05058 & 95.75366 & 0.0291 \\
\hline
\end{tabular}

Trace test indicates 3 co integrating eqn(s) at the 0.05 level

* Significant at the 0.05 level

**MacKinnon-Haug-Michelis (1999) p-values

Table 3: Unrestricted Co-integration Rank Test (Maximum Eigen value)

\begin{tabular}{|c|c|c|c|c|}
\hline $\begin{array}{l}\text { Hypothesized No. of } \\
\text { coefficients }\end{array}$ & Eigen Value & Trace Statistics & $\begin{array}{l}\text { 0.05 Critical } \\
\text { Value }\end{array}$ & Probability** \\
\hline None * & 0.979212 & 73.59407 & 52.36261 & 0.0001 \\
\hline At most 1 & 0.908944 & 45.52943 & 46.23142 & 0.0593 \\
\hline None * & 0.979212 & 73.59407 & 52.36261 & 0.0001 \\
\hline
\end{tabular}

Max-eigen value test indicates 1 co integrating eqn(s) at the 0.05 level

* Significant at 5\% level.

**MacKinnon-Haug-Michelis (1999) p-values

Table 2 \& 3 depicts the result of Johansen Cointegration. It shows that the number of cointegrated equation ( 0 ) is none which means there is no co-integrated equation. The trace statistics is greater than the 0.05 critical values, so H05: "Both Stock Returns and Gross Domestic Product of Brazil are not co-integrated", H06: "Both Stock Returns and Gross Domestic Product of Russia are not cointegrated", H07: "Both Stock Returns and Gross Domestic Product of China are not co-integrated", H08: "Both Stock Returns and Gross Domestic Product of South Africa are not co-integrated". The above mentioned null hypotheses (H05, H06, H07, $\mathrm{H} 08$ ) are rejected at $1 \%, 5 \%$ by using co-integration result. The results of co-integration test shows that stock return and Gross Domestic Product are cointegrated with respect to BRCS. And also by analyzing the probability value, the null hypothesis is rejected at $5 \%$ level at none for the Stock return on Gross Domestic Product in BRCS. Therefore, the test indicates that co-integrating exists at $5 \%$.

\section{Granger Causality Test}

The findings of Granger Causality test are given in table 4 to determine the direction of causality. The overall results are summarized as given below: 
Table 4: Results of Granger Causality Test

\begin{tabular}{|c|c|c|c|c|}
\hline Statement for Analysis Tested Variables & Obs. & F-Statistics & Probability & Decision \\
\hline $\begin{array}{l}\text { BRAZIL_STOCK_RETURN does not have Granger Cause } \\
\text { BRAZIL_GROSS DOMESTIC PRODUCT }\end{array}$ & 18 & 9.89612 & $0.0006^{*}$ & Significant \\
\hline $\begin{array}{l}\text { CHINA_GROSS DOMESTIC PRODUCT does not have } \\
\text { Granger Cause BRAZIL_GROSS DOMESTIC PRODUCT }\end{array}$ & 18 & 6.45133 & $0.0862^{* * *}$ & Significant \\
\hline $\begin{array}{l}\text { RUSSIA_GROSS DOMESTIC PRODUCT does not have } \\
\text { Granger Cause BRAZIL_GROSS DOMESTIC PRODUCT }\end{array}$ & 18 & 3.72122 & 0.1462 & $\begin{array}{c}\text { Not } \\
\text { Significant }\end{array}$ \\
\hline $\begin{array}{l}\text { RUSSIA_GROSS DOMESTIC PRODUCT does not have } \\
\text { Granger Cause BRAZIL_GROSS DOMESTIC PRODUCT }\end{array}$ & 18 & 7.21223 & $0.008^{* *}$ & Significant \\
\hline $\begin{array}{l}\text { RUSSIA_STOCK_RETURN does not Granger have Cause } \\
\text { BRAZIL_GROSS DOMESTIC PRODUCT }\end{array}$ & 18 & 7.27040 & $0.007^{*}$ & Significant \\
\hline $\begin{array}{l}\text { SA_GROSS DOMESTIC PRODUCT does not have } \\
\text { Granger Cause BRAZIL_GROSS DOMESTIC PRODUCT }\end{array}$ & 18 & 9.33350 & $0.0001^{*}$ & Significant \\
\hline $\begin{array}{l}\text { CHINA_STOCK_RETURN does not Granger Cause have } \\
\text { BRAZIL_STOCK_RETURN }\end{array}$ & 18 & 2.44110 & 0.3612 & $\begin{array}{c}\text { Not } \\
\text { Significant }\end{array}$ \\
\hline $\begin{array}{l}\text { CHINA_GROSS DOMESTIC PRODUCT does not have } \\
\text { Granger Cause BRAZIL_STOCK_RETURN }\end{array}$ & 18 & 8.34170 & $0.0062^{*}$ & Significant \\
\hline $\begin{array}{l}\text { RUSSIA_GROSS DOMESTIC PRODUCT does not have } \\
\text { Granger Cause BRAZIL_STOCK_RETURN }\end{array}$ & 18 & 6.66923 & $0.0329^{* *}$ & Significant \\
\hline $\begin{array}{l}\text { RUSSIA_STOCK_RETURN does not Granger have Cause } \\
\text { BRAZIL_STOCK_RETURN }\end{array}$ & 18 & 8.18140 & $0.0627^{* * *}$ & Significant \\
\hline $\begin{array}{l}\text { CHINA_STOCK_RETURN does not Granger Cause have } \\
\text { CHINA_GROSS DOMESTIC PRODUCT }\end{array}$ & 18 & 9.97112 & 0.3058 & $\begin{array}{c}\text { Not } \\
\text { Significant }\end{array}$ \\
\hline $\begin{array}{l}\text { SA_STOCK_RETURN does not Granger Cause have } \\
\text { BRAZIL_STOCK_RETURN }\end{array}$ & 18 & 9.59504 & $0.0003^{*}$ & Significant \\
\hline $\begin{array}{l}\text { RUSSIA_GROSS DOMESTIC PRODUCT does not have } \\
\text { Granger Cause CHINA_GROSS DOMESTIC PRODUCT }\end{array}$ & 18 & 9.02204 & $0.0004^{*}$ & Significant \\
\hline $\begin{array}{l}\text { RUSSIA_STOCK_RETURN does not have Granger Cause } \\
\text { CHINA_GROSS DOMESTIC PRODUCT }\end{array}$ & 18 & 7.34891 & $0.019^{* *}$ & Significant \\
\hline $\begin{array}{l}\text { SA_GROSS DOMESTIC PRODUCT does not have } \\
\text { Granger Cause CHINA_GROSS DOMESTIC PRODUCT }\end{array}$ & 18 & 8.99801 & $0.0012^{*}$ & Significant \\
\hline $\begin{array}{l}\text { SA_STOCK_RETURN does not have Granger Cause } \\
\text { CHINA_GROSS DOMESTIC PRODUCT }\end{array}$ & 18 & 5.30802 & $0.0180^{* *}$ & Significant \\
\hline $\begin{array}{l}\text { RUSSIA_GROSS DOMESTIC PRODUCT does not have } \\
\text { Granger Cause CHINA_STOCK_RETURN }\end{array}$ & 18 & 9.16902 & $0.0018^{*}$ & Significant \\
\hline
\end{tabular}




\begin{tabular}{|l|c|c|c|c|}
\hline $\begin{array}{l}\text { RUSSIA_STOCK_RETURN does not have Granger Cause } \\
\text { CHINA_STOCK_RETURN }\end{array}$ & 18 & 4.21904 & 0.6519 & $\begin{array}{c}\text { Not } \\
\text { Significant }\end{array}$ \\
\hline $\begin{array}{l}\text { SA_GROSS DOMESTIC PRODUCT does not have } \\
\text { Granger Cause CHINA_STOCK_RETURN }\end{array}$ & 18 & 3.31401 & 0.8765 & $\begin{array}{c}\text { Not } \\
\text { Significant }\end{array}$ \\
\hline $\begin{array}{l}\text { SA_STOCK_RETURN does not have Granger Cause } \\
\text { CHINA_STOCK_RETURN }\end{array}$ & 18 & 4.60211 & 0.1603 & $\begin{array}{c}\text { Not } \\
\text { Significant }\end{array}$ \\
\hline $\begin{array}{l}\text { RUSSIA_STOCK_RETURN does not have Granger Cause } \\
\text { RUSSIA_GROSS DOMESTIC PRODUCT }\end{array}$ & 18 & 7.81032 & $0.0063^{*}$ & Significant \\
\hline $\begin{array}{l}\text { SA_GROSS DOMESTIC PRODUCT does not have } \\
\text { Granger Cause RUSSIA_GROSS DOMESTIC PRODUCT }\end{array}$ & 18 & 7.29403 & $0.0758^{* * *}$ & Significant \\
\hline $\begin{array}{l}\text { RUSSIA_STOCK_RETURN does not have Granger Cause } \\
\text { RUSSIA_GROSS DOMESTIC PRODUCT }\end{array}$ & 18 & 7.81032 & $0.0043^{*}$ & Significant \\
\hline $\begin{array}{l}\text { SA_STOCK_RETURN does not have Granger Cause } \\
\text { RUSSIA_GROSS DOMESTIC PRODUCT }\end{array}$ & 18 & 7.17710 & $0.0108^{* *}$ & Significant \\
\hline $\begin{array}{l}\text { SA_STOCK_RETURN does not have Granger Cause } \\
\text { RUSSIA_STOCK_RETURN }\end{array}$ & 18 & 8.57143 & $0.0084^{*}$ & Significant \\
\hline $\begin{array}{l}\text { SA_STOCK_RETURN does not have Granger Cause } \\
\text { SA_GROSS DOMESTIC PRODUCT }\end{array}$ & 18 & 7.63047 & $0.0437^{* *}$ & Significant \\
\hline
\end{tabular}

Source: Compiled Data significant at $10 \% * * *, 5 \% * *, 1 \% *$

Table 4 reveals the result of Granger Causality test. Both Stock Return and Gross Domestic Product have an impact on their indices. Brazilian GDP causes Stock Return on Brazil, China, Russia and South Africa at $10 \%, 5 \%$ and $1 \%$ level. Chinese Gross

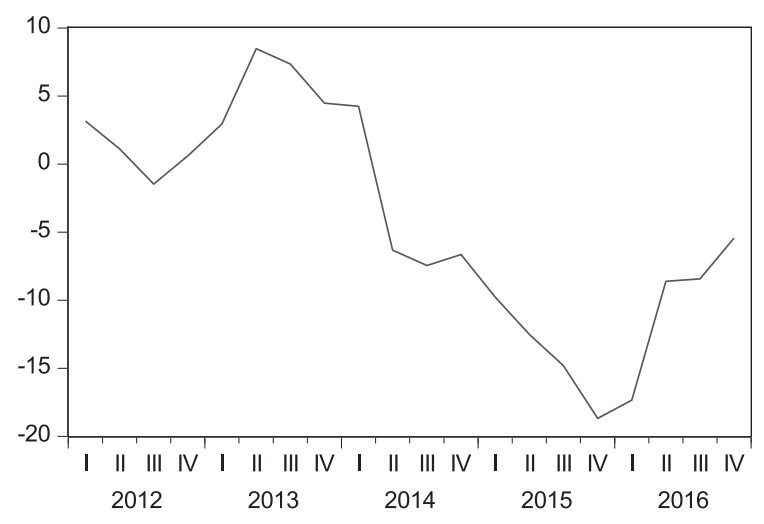

Figure1: Brazil GDP
Domestic Product cause Stock Return on BRCS at 10\%, 5\% and $1 \%$ level. Russian GDP causes Stock Return on BRCS at 10\%,5\% and 1\% level. South African Gross Domestic Product also causes Stock Return on BRCS at $10 \%, 5 \%$ and $1 \%$ level.

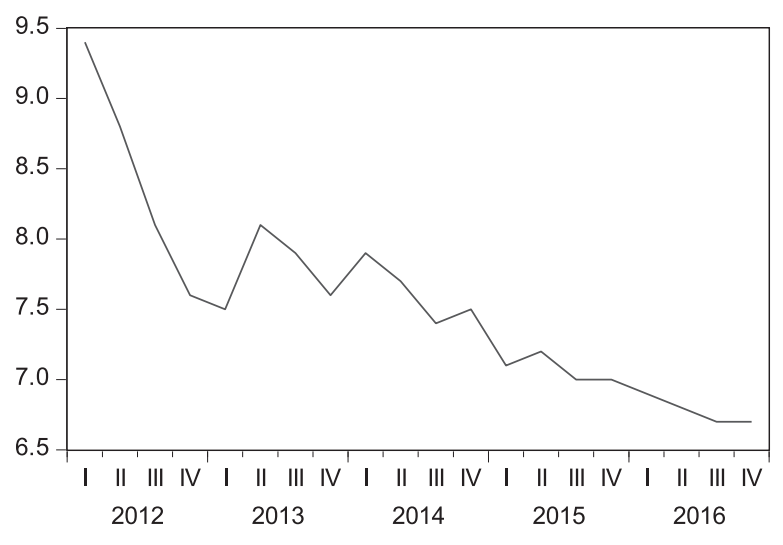

Figure 3: China GDP 


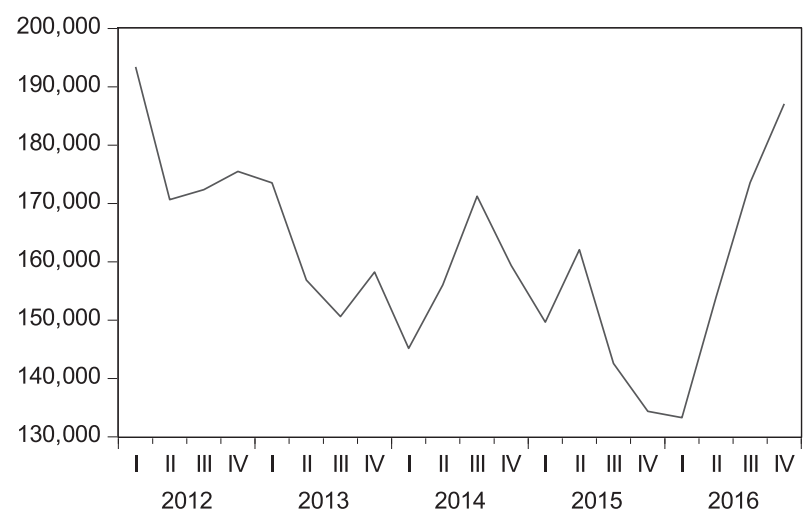

Figure 2 : Brazil Stock return

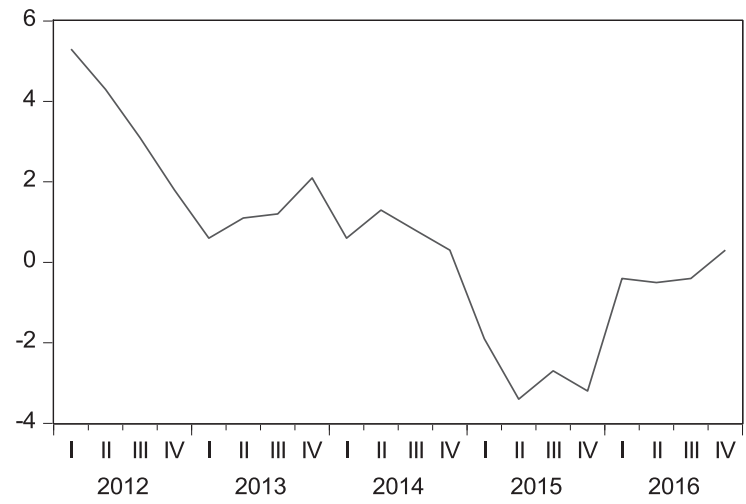

Figure 5 : Russia GDP

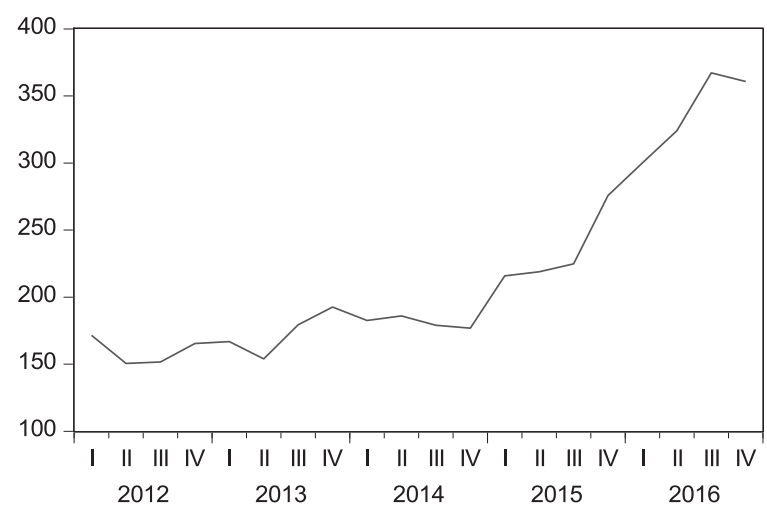

Figure 6 : Russia Stock Return

Figure $1 \& 2$ show the clear picture of movement of Brazilian Gross Domestic Product (GDP) and Stock return. The movement of GDP is very much similar and parallel trend in nature. It shows that Brazilian GDP and Stock return are moving in a same direction. And it depicts that there is a strong association between Brazilian GDP and Stock return.

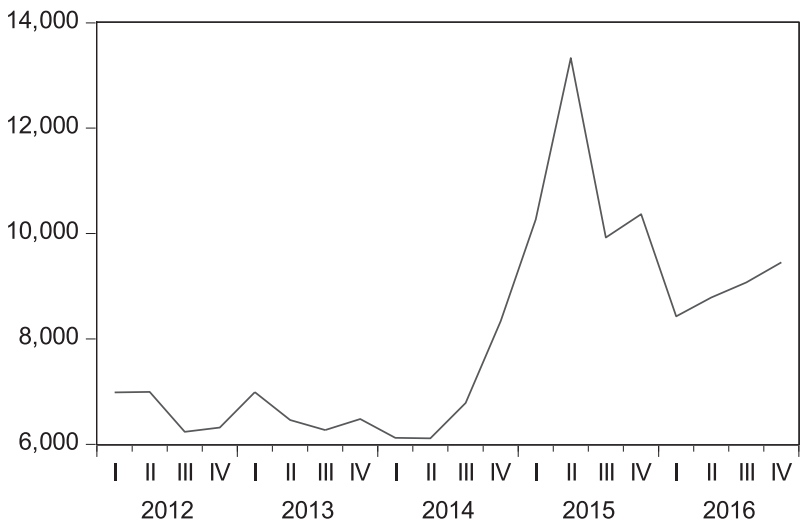

Figure 4 : China Stock Return

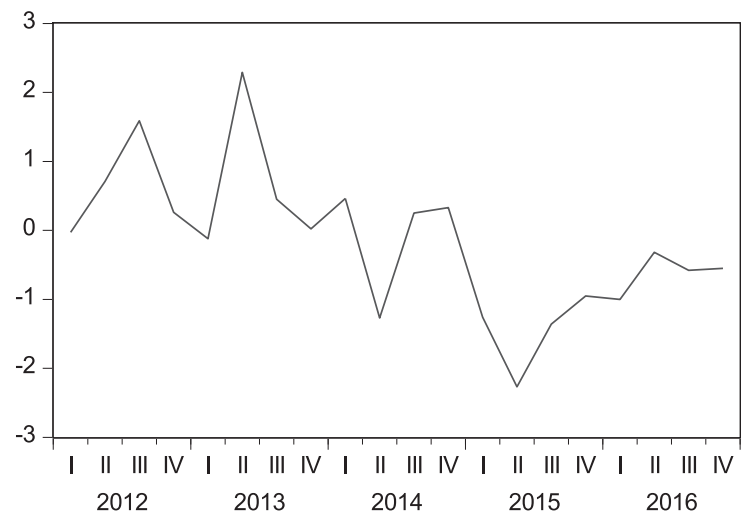

Figure 7 : South Africa GDP

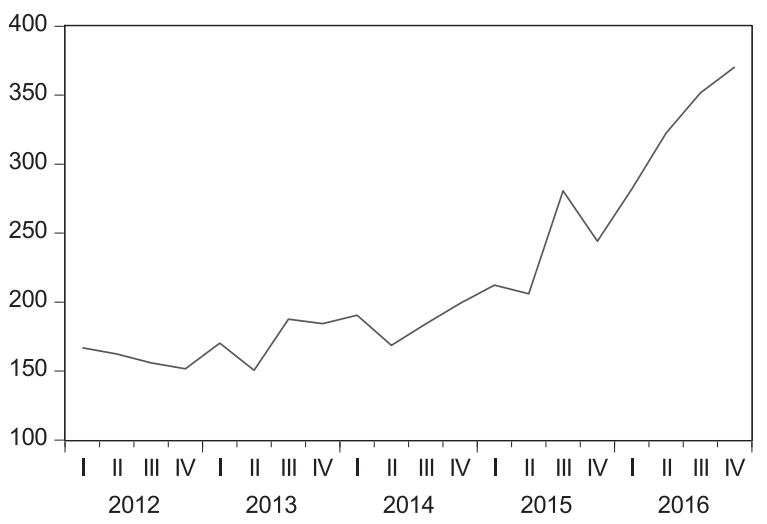

Figure 8 : South African Stock Return

Figure $3 \& 4$ show that Chinese GDP and Stock return. The movement of GDP and Stock return is almost different. Stock return is upward reaction and GDP is downward reaction in the 2016 are having a strong connection. And it reveals that the GDP and Stock return are following similar trend. 
Figure $5 \& 6$ depict the picture of movement of GDP and Stock return of Russian. The movement of GDP is very much similar and parallel trend in nature. It shows that Russian GDP and Stock return are moving in a same direction. And it depicts that there is a strong association in Russian GDP and Stock return.

Figure $7 \& 8$ show that time series plot of South African GDP and SR reveals that both the series displays volatility clustering and volatility. Both the series show similar distributions. And it shows that there is a strong association between South African GDP and Stock return.

\section{The major findings of the study are given below:}

The study explored that GDP and Stock returns are stationary with respected to BRCS. The Johansan Cointegration test revealed that the Gross Domestic Product and Stock return of BRCS are co- integrated. Granger Causality test inferred that there is a granger cause of GDP and stock return of BRCS are co-integrated. And further, the study also revealed that the movement of GDP and Stock return are having a similar trend with respect to BRCS.

\section{Concluding Remarks}

This study concludes that the GDP and Stock return are having a strong connection. It is revealed that GDP and Stock return are co-integrated. The study found a strong association between GDP and SR in connection with BRCS.

\section{Scope of the further Research}

Since the study is concentrated only on the selected two indices i.e. GDP and Stock return. The study has covered the period only for 2012-2016 five years. The countries like BRCS market cannot be accessed with the two indices i.e. GDP and Stock return. Some more variables like WPI, IIP, Oil Price and unemployment rate may be included to get comprehensive results for further studies. The study may include the data of India if it is available for the said study period.

\section{REFERENCES}

1) Retrieved on October 10, 2018, from BRICS Summit: ttps://www.google.co.in/search? source =h p \& e i = g Ii 9 W 6 v y s 2S 9QO1pHADw\&q=brics+summit\&oq.

2) Allen, Chakrabati and De (2007), India Financial System, SSRN Online Library. 21-51.

3) Amano, E.A and Van Norden, (1998), Oil Prices and the Rise and fall of the US Real Exchange Rate. Journal of International Money and Finance, 17: 299-316.

4) Reena, A., Carla, I., and L. Ricardo. 1999. Volatility in emerging stock markets. The Journal of Financial and Quantitative Analysis 34(1): 33-55.

5) Anandan, M. Ramaswamy, and S. Sridhar. (2013), Crude Oil Price Behavior and Its Impact on Macroeconomic Variable: A Case of Inflation. The Gandhigram Rural Institute-Deemed University, Dindigul Tamilnadu 13(6): 147-61.

6) Aparna, A. (2013), Impact of Oil Price on the Indian Economy. Impact of Oil Prices on the Indian Economy 5(28): 141-7.

7) Bhagirath, S. B. (2013), Whither Global Economic Governance? The Emerging Role of BRICS: An Alternative. Indian Journal of Asian Affairs 26(2): 75-92.

8) Cavalvanti, $T$ and J.T. Jalles, (2013), Macroeconomic Effects of Oil Price Shocks in Brazil and in the United States. Applied Energy, 104: 475-86.

9) David, B. H., and M. Tomenendal. 2012. The emerging market hype-putting market size and in BRIS countries into perspective. Critical Perspectives on International Business 8(3): 24158.

10) Ghosh, S. (2011), Examining Crude Oil PriceExchange Rate Nexus for India During the Period of Extreme Oil Price Volatility. Applied Energy, 88: 1886-9.

11) Ghosh, T. (2016), Oil Price, Exchange Rate and 
the Indian Macro Economy. Indira Gandhi Institute of Development Research:1-16.

12) Gurloveleen, K. and B.S. Bhatia. (2015), An Impact of Macroeconomic Variables on the functioning of Indian Stock Market: A Study of Manufacturing firms of BSE 500. Journal of Stock and Forex Trading, 1-9.

13) Jung, S. J. and P. J. Marshall (1985), Exports Growth and Causality in Developing Countries. Journal of Development Economics, 18: 1-12.

14) Jyoti,K. and J. Mahakud. (2015), Relationship Between Conditional Volatility of Domestic Macroeconomic Factors and Conditional Stock Market Volatility: Some Further Evidence from India. Asia-Pacific Financial Markets 22(1): 87111.

15) Mohan, R. (2007), India's Financial Sector Reforms: Fostering Growth While Containing Risk, Address at Yale University.

16) Mohanamani, P. and T. Sivagnanasithi. (2014), Indian Stock Market and Aggregate Macroeconomic Variables: Time Series Analysis. IOSR Journal of Economics and Finance (IOSRJEF) 3(6): 68-74.

17) Nathan, T. (2000), Influences on the Stock Market: An Examination of the Effect of Economic Variables on the S\&P 500. The park Place Economist 1(9): 91-100.

18) Olasunkanmi, I. O., and P. N. Ifeakachukwu. 2011. Stock market volatility and macroeconomic variables volatility in Nigeria: An exponential GARCH Approach. Journal of Economics and Sustainable Development 2(10): 28-43

19) Rahman, M and M. Mustafa (1997). Dynamics of Real Exports and Real Economic Growths in 13 Selected Asian Countries. Journal of Economic Development, 22: 81-95.

20) Rakesh, Kumar. (2013), The Effect of Macroeconomic Factors on Indian Stock Market Performance. A Factor Analysis Approach, IOSR Journal of Economics and Finance (IOSR-JEF) 1(3): 14-21.

21) Raurava, J. (2004). The Role of Oil Prices and the Real Exchange Rate in Russia's Economy-a Cointegration Approach, Journal of Comparative
Economics, 32: 315-27.

22) Rousseau, L. and P. Wachtel. (2000), Equity market and growth: Cross country evidence on timing and outcomes, 1998-1995, Journal of Banking and Finance, (8)24:193-57.

23) Rolland, E. Sonia. 2013. The BRICS contributes to the architecture and norms of international economic law. International Law in a Multipolar world 107(16): 164-70.

24) Sagarika, M., and S. Harminder. 2010. Do macroeconomic variables explain stock-market returns? evidence using a semi-parametric approach. Journal of Asset Management Macmillan Publisher Ltd 1-13.

25) Srinivasan, P. (2016), Causal Nexus between Export and Growth: BRICS Nations, SCMS Journal of Indian Management, January-March, 67-80.

26) Vanita, T. and S. Ritika. (2014), Stock Market Performance and Macroeconomic Factors: The Study of Indian Equity Market. Global Business Review New Delhi: SAGE Publications 15(2): 291-316. 